\title{
"Corporate dynamism and cash holding decision in listed manufacturing firms in
}

Nigeria"

\begin{tabular}{|c|c|}
\hline \multirow{7}{*}{ AUTHORS } & Emmanuel Ozordi iD https://orcid.org/0000-0001-6628-8631 \\
\hline & R http://www.researcherid.com/rid/G-2971-2018 \\
\hline & Dorcas Titilayo Adetula (D https://orcid.org/0000-0001-5411-0019 \\
\hline & Damilola Felix Eluyela (D https://orcid.org/0000-0002-3080-6385 \\
\hline & R http://www.researcherid.com/rid/B-1038-2017 \\
\hline & Adenike Aina (D https://orcid.org/0000-0001-9051-0378 \\
\hline & Mautin Arinola Ogabi iD https://orcid.org/0000-0001-8235-0204 \\
\hline ARTICLE INFO & $\begin{array}{l}\text { Emmanuel Ozordi, Dorcas Titilayo Adetula, Damilola Felix Eluyela, Adenike } \\
\text { Aina and Mautin Arinola Ogabi (2019). Corporate dynamism and cash holding } \\
\text { decision in listed manufacturing firms in Nigeria. Problems and Perspectives in } \\
\text { Management, 17(4), 1-12. doi:10.21511/ppm.17(4).2019.01 }\end{array}$ \\
\hline DOI & http://dx.doi.org/10.21511/ppm.17(4).2019.01 \\
\hline RELEASED ON & Friday, 11 October 2019 \\
\hline RECEIVED ON & Tuesday, 12 February 2019 \\
\hline \multirow[t]{2}{*}{ ACCEPTED ON } & Wednesday, 19 June 2019 \\
\hline & $((c)) \overline{E Y}$ \\
\hline LICENSE & $\begin{array}{l}\text { This work is licensed under a Creative Commons Attribution } 4.0 \text { International } \\
\text { License }\end{array}$ \\
\hline JOURNAL & "Problems and Perspectives in Management" \\
\hline ISSN PRINT & $1727-7051$ \\
\hline ISSN ONLINE & $1810-5467$ \\
\hline PUBLISHER & LLC “Consulting Publishing Company "Business Perspectives" \\
\hline FOUNDER & LLC "Consulting Publishing Company "Business Perspectives" \\
\hline
\end{tabular}

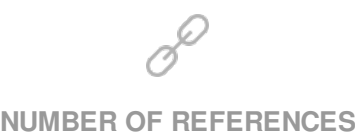

44

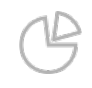

NUMBER OF FIGURES

0

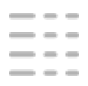

NUMBER OF TABLES

6

(C) The author(s) 2022. This publication is an open access article. 


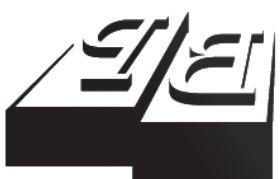

BUSINESS PERSPECTIVES

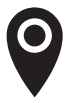

LLC "CPC "Business Perspectives" Hryhorii Skovoroda lane, 10, Sumy, 40022, Ukraine

www.businessperspectives.org

Received on: $12^{\text {th }}$ of February, 2019 Accepted on: $19^{\text {th }}$ of June, 2019

(C) Emmanuel Ozordi, Dorcas Titilayo Adetula, Damilola Felix Eluyela, Adenike Aina, Mautin Arinola Ogabi, 2019

Emmanuel Ozordi, Ph.D. Student, Lecturer, Department of Accounting, Covenant University, Nigeria.

Dorcas Titilayo Adetula, Ph.D. Associate Professor, Department of Accounting, Covenant University, Nigeria.

Damilola Felix Eluyela, Lecture of Accounting, Department of Accounting and Finance, Landmark University, Nigeria.

Adenike Aina, M.Sc., Department of Accounting, Covenant University, Nigeria.

Mautin Arinola Ogabi, M.Sc., Department of Accounting, Covenant University, Nigeria.

\section{(ㄷ)(ㄱ)}

This is an Open Access article, distributed under the terms of the Creative Commons Attribution 4.0 International license, which permits unrestricted re-use, distribution, and reproduction in any medium, provided the original work is properly cited.
Emmanuel Ozordi (Nigeria), Dorcas Titilayo Adetula (Nigeria),

Damilola Felix Eluyela (Nigeria), Adenike Aina (Nigeria), Mautin Arinola Ogabi (Nigeria)

\section{AND CASH HOLDING DECISION IN LISTED MANUFACTURING FIRMS IN NIGERIA}

\begin{abstract}
Cash holding decision is a very crucial decision that strongly affects the performance of an organization. Corporate dynamism as a corporate governance tool was explored in this study in order to establish its relationship with cash holding decision in listed manufacturing companies in Nigeria. Board skill, female leadership, foreign directors, board ownership and directors' compensation were used as proxies for corporate dynamism. A panel regression model was adopted in this study to examine the implication of corporate dynamism on cash holding decisions spanning six years from 2012 to 2017. Random sampling technique was employed in order to arrive at thirty firms out of thirty-seven listed manufacturing firms, which comprised industrial and consumer goods sector. Board ownership and the existence of foreign expatriates were found to have a significant effect on cash holding decisions. It is concluded that directors with significant holdings tend to be more aggressive towards activities that enhance the performance of a firm, one of which is ensuring that optimal level of cash is held at a particular point in time in order to guide against liquidity problems, which may be caused by overtrading or even keeping excess idle cash, which is supposed to be invested in profitable ventures. Also, the fact that the existence of foreign expatriates will affect cash holding decisions, which may be justified by the fact foreign expatriates are displaying expertise because of diverse experience that they have been able to gain from different parts of the world.
\end{abstract}

\section{Keywords board ownership, board skill, cash holdings, director compensation, female leadership}

\section{JEL Classification G32, G34, M41}

\section{INTRODUCTION}

The decision of cash holding is very germane to the survival and growth of a firm, and a growing literature has emerged recently to explain the implication and determinants on firms. In the developed economy, a recent report by Deloitte shows that there has been an increase in cash holdings over the past three decades. For example, in the United States, Han and Box (2017) assert that US firms account for $\$ 5$ trillion in cash holdings between 1990 and 2000. This amounts to $10 \%$ of the annual gross domestic product (GDP) of the US. Subsequently, Alam (2010) opined that Japanese firms hold \$2.1 trillion in cash, which amounts to $44 \%$ of their GDP. For Korean firms, similar figures were recorded by Mosavi, Karimipoua, Zarei, and Heidari (2015) who highlight that $\$ 4.4$ billion was withheld by Korean firms in cash and this is equal to $34 \%$ of their GDP. The aforementioned numbers signify that cash holdings decisions are important to every corporate organization.

However, this decision is highly influenced by the board of directors (top-level management). They are responsible for determining the 
amount of cash that is to be retained or withheld by the firm within a financial period (Kuan, $\mathrm{Li}, \& \mathrm{Chu}$, 2011). The competence of the board is of the utmost importance in addressing and justifying cash reserves. One of the underlying assumptions when preparing financial statements of every firm is going concern. It's expected of every organization to be seen as a going concern. Cash is very important to the going concern of the firm. This is very crucial to the going concern of the firm reason being that cash and cash equivalent are liquid assets meant to increase shareholders value by investing in profitable engagements, drastically minimize cost, and the peculiarity of cash not overlooked. Hence, the agent (top-level managers) saddled with this responsibility need to be equipped on how to make informed and timely decisions in cash management (Sunden \& Surette, 1998).

There has been a dichotomy in theories; Santosuosso (2015) noted that the pecking order theory assumes that agent (managers) act in the best interest of their principal (shareholders). It's believed that the agency conflict (conflict of interest) is absent under this theory. This suggests that managers are allowed to hold cash in the company and use for profitable investments. This is in line with the pecking order theory that internal resources should be considered before external resource (Orens \& Reheul, 2013; Scordis et al., 2017). On the flip side, Connor and Yaghoubi (2016) opined that free cash flow theory and agency theory highlights that agency conflicts arise noting that managers don't always act in the best interest of the shareholders due to their own personal benefit. They act in their own personal profiting rather than increasing the wealth of the shareholders. Based on this premise, there is a fear that when an agent (managers) holds too much cash, they might mismanage the fund and leads to agency problem (Al Zararee \& Al-Azzawi, 2014).

However, this study is based on agency theory. Agency theory is one of the most frequently adopted theoretical frameworks by finance and economics researchers in understanding the linkage between cash holding decisions and corporate governance variables. The existence of agency theory is based on the relationship between principals (shareholders) and agents (board members), which arise as a result of separation in ownership and control of a business enterprise, such that these shareholders appoint the board members to ensure the creation of a disciplined atmosphere, setting of timely and achievable strategic plan, and the effective control of the management team, thereby ensuring firm performance, which will lead to maximization of shareholder's value (Connor \& Yaghoubi, 2016). In ensuring these, it is important for board members to ensure adequate management of company cash by investing it into profitable ventures.

Subsequently, empirical review on the relationship between cash holdings and corporate governance that have focused on developed and developing economies is inconclusive. For example, in Belgium, Orens and Reheul (2013) examine the idiosyncratic manager specific influence on SMEs cash holdings; Amess, Banerji, and Lampousis (2015) consider the causes and consequence of corporate cash holdings in the United States; the Taiwan context (Kuan et al., 2011) examines the relationship between corporate governance and cash policy within family-controlled firms; the Vietnam context (Thi \& Nhan, 2016) presents a review of cash holdings and corporate governance mechanisms and Al-Najjar and Clark (2017) explore the relationship amid cash holdings and internal, external governance mechanisms in Middle East and North African countries. However, there has been a dearth of literature in Nigerian economy. Against this conjuncture, this study aims to explore the influence a robust board has on manufacturing firm's decision to hold cash.

The next section highlights literature review and hypotheses development, section 2 shows the methodological approach applied in this study, while section 3 presents the results and discussion of findings and finally conclusion and recommendations were provided in the last section. 


\section{LITERATURE REVIEW AND HYPOTHESES DEVELOPMENT}

Several corporate governance attributes have been given attention in recent academic literature. Some of these attributes are board meeting frequency (Eluyela et al., 2018a); foreign directorships (Ozordi, Uwuigbe, Teddy, Ikimapayi, \& Gbenedio, 2018); and board independence (Nadeem, Zaman, \& Saleem, 2017). Despite these prior empirical studies on various board attributes, in this study, we examined five different variables that measure corporate dynamism in relation to cash holding decision. These are board skill, female leadership, foreign directors, board ownership and director compensation.

\subsection{Board skill and cash holding decision}

The level of education, experience and exposure determines the skill board members acquire over time. The formal educational experience of CEO irrespective of any educational background affects the managerial decisions top executives make and ultimately has an effect on the value and survival of the firm (Kuan et al., 2011). Since cash holding decisions determine ultimately the survival of the firm, the risk associated with cash holding decisions is to be considered, in a bid to balance liquidity and profitability. Scordis et al. (2017) noted that highly educated CEOs are less risk averse and have a better understanding of the cash implications of various firm needs and investment opportunities that might be right for the firm in the market. They posit that they will be less concerned about holding of cash. Hence, higher educated CEOs are likely to spend their firm cash resources, managing firm cash needs effectively and taking profitable investment opportunities as compared to lower educated CEOs. Lower educated CEOs will qualify for any CEO without a master's degree or MBA (i.e. CEO with only first degree) (Amess et al., 2015). However, Jamil, Anwar, Afzaal, Tariq, and Asif (2016) posit that the decision of holding a well-structured cash system is not mainly influenced by board skill. This conflicting evidence in empirical literature leads us to the conjuncture that:
$H_{01}$ : There is no significant relationship between board skill and cash holding decisions in listed manufacturing firms in Nigeria.

\subsection{Female leadership and cash holding decision}

In previous literature, the relationship between female leadership and cash holding remains inconclusive. We established two objectives functions or motive for female leadership, that is the agency cost motives and precautionary motives. From agency cost motive, when a woman is included in the board of directors, Hilgen (2015), Thi and Nhan (2016), believe that this will enhance the board effectiveness and monitoring quality thereby increasing shareholders wealth, as well as influencing the organizations monitoring quality positively and the corporate board as a whole (Adams \& Ferreira, 2009). Also, the presence of female leadership helps organizations by connecting them with shareholders and making provision for legitimacy with respect to numerous stakeholders like employees, investors and so on (LückerathRovers, 2010). Another benefit of having a female leader on board is the reduction of opportunistic behavior of managers, which ultimately results in the elimination of agency cost. Alternatively, from the precautionary motives, previous researchers have noted that females tend to be more risk averse (Ahsan \& Ullah, 2013) and less confident in the decision making process as compared to male board members (Bhagat \& Obreja, 2012). Accordingly, board that are led by female directors do not make risky investment because of her risk appetite, which is in contrast to their male counterparts who tend to make more confident thereby taking on riskier investments (Agnew et al., 2003; Barber \& Odean, 2001; Barsky et al., 1997; Faccio et al, 2012; Huang \& Kisgen, 2013; Sunden \& Surette, 1998). For example, a study from (Huang \& Kisgen, 2013) reveals that male executives tend to make more purchases and issuance of debt than female executives. They always want to play safe and take precautionary measures before diving into a new investment. Under this motive, it's believed that there is no need for cash holding and that a negative relationship exists between female leadership and cash holding decision (Alam, 2010; Sabbadini \& Lim, 2011). Against this conjuncture, we hypothesize that: 
$H_{02}:$ There is no significant association between female leadership and cash holding decisions in listed manufacturing firms in Nigeria.

\subsection{Foreign directors and cash holding decision}

The issue of the firm having a diverse board has been a consistent debate in recent finance literature (Nadeem, Zaman, \& Saleem, 2017; Ozordi, Uwuigbe, Teddy, Tolulope, \& Eyitomi, 2018). Diversity can be in age, gender, experience and nationalities. There has been several empirical evidence on the presence of foreign directors and performance, but few regarding cash holding decision. Peck-Ling et al. (2016) investigated the effect of foreign ownership and foreign directors on the profitability of Malaysian listed companies between 1999 and 2010. Using a sample of 348 Malaysian firms, the result shows that foreign equity ownership, the appointment of foreign chairman and foreign chief executive directors did not have a significant relationship with return on equity of the sampled firms. However, foreign directors on board have a significant effect on return on equity. Subsequently, in the Mexican context, Reyna (2017) found a positive relationship amidst the aforementioned constructs. However, Jeon and Ryoo (2013) and Benavides et al. (2016) found an insignificant association between foreign directors and dividend pay-out structure in India and Korea, respectively.

In this study, foreign directors are expatriates who have nationalities outside of Nigeria. Ozordi, Uwuigbe, Teddy, Tolulope, and Eyitomi (2018) are of the opinion that for a firm to acquire diverse skills, innovations and ideas, they should employ the services of expatriates from different parts of the world. Schoubben and Uytbergen (2014) posit that experience, knowledge and skill of foreign board members will result in an effective and efficient cash holding decision in firms. However, Hilgen (2015) opined that whether foreign directors are present on board or not, cash holding decisions are not significantly affected. Against this inconclusive result in empirics, the third hypothesis is stated as follows:

\section{$H_{03}:$ There is no significant relationship between foreign directors and cash holding decisions in listed manufacturing firms in Nigeria.}

\subsection{Board ownership and cash holding decision}

Prior literature on the relationship between board ownership and cash holding decision provides mixed evidence. Kuan et al. (2011) argued that there is a positive relationship between board ownership and cash holding decisions, this is because board with higher ownership percentage tends to lead to greater performance in organizations Adams \& Ferreira, 2009; Lambert et al., 2007). Also, an increased director's ownership stakes in the firm, managers are less likely to pursue activities that will result in value reduction for the company. They would be able to use their oversight power to ensure proper use of cash when making investment decisions. Jamil, Anwar, Afzaal, Tariq, and Asif (2016) also found a similar result. On the other hand, if managers own a large share of their personal wealth in company's shares, this might make managers risk averse when making investment decisions (AlNajjar \& Clark, 2017; Amess et al., 2015). They argue that a negative relationship exists between board ownership and cash holding decision. Scordis et al. (2017) noted that the influence of board ownership on cash holding is U-shaped. Against this empirical evidence, we hypothesize as follows:

$H_{04}$ : There is no significant association between board ownership and cash holding decisions in listed manufacturing firms in Nigeria.

\subsection{Director compensation and cash holding decision}

Beside board skill, female leadership, foreign directors and board ownership, the director compensation is also an important variable to consider. Liu and Mauer (2011) identified the main components of director compensation, which comprises of basic pay, bonus, pensions and other benefits in kind. Compensation serves as motivation and satisfaction for directors, which have a huge effect on firm value. Santosuosso (2015) points out that when the board of directors are highly paid, shareholders' wealth is positively related. For organizations to bring out the best from the directors, they have to be provided with appropriate motivations and compensations (Frydman \& Saks, 2010). Lambert et al.'s (1991) study shows that higher compensation results in greater amount of cash holding owing to the risk averse and 
under-diversified it seems like here is missed something of the board. In this situation, the firms keep more cash to take all investment opportunities to increase the firm value. This evidence above supports that the compensation the board of directors has an impact on the corporate cash holding level as they have a great influence on the liquidity of the firms (Liu \& Mauer, 2011). For example, the study by Vo and Phan (2013) in Vietnam shows that the compensation of the board of directors is also an important element that influences the organization's operations. However, Eluyela et al. (2018b) noted that when directors are well compensated, it helps to reduce agency conflict. This conflict of interest may exist between CEOs and board of directors. The bonus scheme given to the director for achieving a certain level of performance also helps to reduce these conflicts. Directors will always strive to attain this level of performance in order to get the bonus, they will ensure that the company cash is well managed towards attaining this level of performance expected from them. In order to solve this conflict, such a firm should not hold high level of cash (Fryman \& Saks, 2010). This is due to such firm having beyyer performance and can simply borrow money from external parties like banks. Nevertheless, Kuan et al. (2011) noted that excess director compensation can lead to underperformance of firms. This is because the board does not wish to take all investment opportunities in order to have a high level of cash reserve to obtain more compensation. Therefore, it needed to determine whether director compensation is significantly associated with cash holding decision.

\section{$H_{05}:$ There is no significant association between director compensation and cash holding decisions in listed manufacturing firms in Nigeria.}

\section{MATERIALS AND METHODS}

In order to achieve the aforementioned objectives, a sample of thirty firms was selected randomly from a population of thirty-seven manufacturing firms in line with Krejcie and Morgan (1970), Uwalomwa, Olamide, and Francis (2015) who are of the opinion that $5 \%$ of a population is the minimum sample size expedient to make inferences on the entire population. Furthermore, the choice of this sector stems from the major contribution of the manufacturing firm to the growth of the economy (Asaleye, Adama, \& Ogunjobi, 2018; Oladipo, Iyoha, Fakile, Asaleye, \& Eluyela, 2019). However, the possible choice of thirty firms was necessitated by the availability and accessibility of data within the period under consideration from independent firms' annual report. The annual report is the legitimate blueprint of any external and internal investor in making decisions. Hence, this report was explored to extract information on the explanatory construct (female leadership, director compensation, foreign directors, board skill, board ownership) and the explained construct (cash holding decision), respectively. Spanning from 2012 to 2017 being six years was duly scrutinized under this study. The Hausman test was conducted to ascertain if the fixed effect model (FE) or random effect (RE) model panel regression is ideal to explore the impact of corporate dynamism and cash holding decision on listed manufacturing firm (Asaleye, Popoola, Lawal, Ogundipe, \& Ezenwoke, 2018).

Table 1. Summary of variables

\begin{tabular}{|c|c|c|}
\hline Variable & $\begin{array}{c}\text { Item } \\
\text { (proxies) }\end{array}$ & Measurement \\
\hline Dependent & $\begin{array}{l}\text { Cash holdings } \\
\text { decision (CHD) }\end{array}$ & $\begin{array}{l}\text { Cash and cash equivalent } \\
\text { divided by the book value of } \\
\text { total assets }\end{array}$ \\
\hline \multirow{5}{*}{ Independent } & $\begin{array}{l}\text { Female } \\
\text { leadership (FL) }\end{array}$ & $\begin{array}{l}\text { The proportion of female } \\
\text { directors against total board } \\
\text { members yearly }\end{array}$ \\
\hline & $\begin{array}{l}\text { Director } \\
\text { compensation } \\
\text { (DCOM) }\end{array}$ & Directors fee annually \\
\hline & $\begin{array}{l}\text { Foreign } \\
\text { directors (FD) }\end{array}$ & $\begin{array}{l}\text { The proportion of foreign } \\
\text { directors on the board divided } \\
\text { by the total number of } \\
\text { directors on the board yearly }\end{array}$ \\
\hline & $\begin{array}{l}\text { Board skill } \\
\text { (BSKILL) }\end{array}$ & $\begin{array}{l}\text { Proxied by the level of } \\
\text { qualification on top level } \\
\text { management (if they have } \\
\text { a Dr or Prof on the board } 1 \\
\text { otherwise } 0 \text { ) }\end{array}$ \\
\hline & $\begin{array}{l}\text { Board } \\
\text { ownership } \\
\text { (BOWN) }\end{array}$ & $\begin{array}{l}\text { The percentage of directors' } \\
\text { shares against total compare } \\
\text { share annually }\end{array}$ \\
\hline \multirow{3}{*}{ Control } & $\begin{array}{l}\text { Board size } \\
\text { (BSIZE) }\end{array}$ & $\begin{array}{l}\text { The numbers of directors on } \\
\text { the board }\end{array}$ \\
\hline & Leverage (LEV) & Annual liabilities to asset \\
\hline & $\begin{array}{l}\text { Profitability } \\
\text { (PROF) }\end{array}$ & $\begin{array}{l}\text { Profit ascertained after tax } \\
\text { annually }\end{array}$ \\
\hline
\end{tabular}




\subsection{Model specification}

In this work, the model shown below was adapted from the work of Thi and Nhan (2018). The equation 1 is shown below:

$C H D=f(F L, D C O M, F D, B S K I L L, B O W N)$

When panel data properties were added, we have equation 2 :

$$
\begin{aligned}
& C H D_{i t}=\beta_{0}+\beta_{1} F L_{i t}+\beta_{2} D_{C O M}+ \\
& +\beta_{3} F D_{i t}+\beta_{4} B S K I L L_{i t}+\beta_{5} B O W N_{i t}+\varepsilon_{i t} \text {. }
\end{aligned}
$$

After a critical review of literature, this study employed certain control and independent construct to the model, which was expressed in equation 3 as follows:

$$
\begin{aligned}
& \text { CHD }_{i t}=\beta_{0}+\beta_{1} F L_{i t}+\beta_{2} \text { DCOM }_{i t}+ \\
& +\beta_{3} \text { DD }_{i t}+\beta_{4} \text { BSKILL }_{i t}+\beta_{5} \text { BOWN }_{i t}+ \\
& +\beta_{6} \text { BZISE }_{i t}+\beta_{7} L E V_{i t}+\beta_{8} \text { PROF }_{i t}+\varepsilon_{i t},
\end{aligned}
$$

where $C H D_{i t}$ - cash and cash equivalent with respect to firm-specific and time lag, $F L_{i t}$ - female leadership with respect to firm-specific and time lag, $D C O M_{i t}$ - director compensation with respect to firm-specific and time lag, $F D_{i t}$ - foreign directors with respect to firm-specific and time lag, $B S K I L L_{i t}$ - board skills with respect to firm-specific and time lag, $B O W N_{i t}$ - director shareholdings with respect firm-specific and time lag, BZISE $_{i t}$ - board size with respect to firm-specific and time lag, $L E V_{i t}$ - debt obligation with respect to firm-specific and time lag, $P R O F_{i t}$ - profit ascertained with respect firm-specific and time lag, $\beta_{0}$ - coefficients of parameter, $\varepsilon_{i t}$ - error term, $i$ - sampled firms, $t$ - time trend.

\section{RESULTS AND DISCUSSIONS}

Table 2 illustrates the summary of the interconnectivity amidst constructs. The decision to hold cash was explored from each sampled firms' cash and cash equivalent balances in their annual reports clearly expressing each firm's decision to hold cash and its equivalent. However, the summary shows a range of $1 \%$ to $66 \%$ of these firm hold cash with an average mean of $9 \%$ simply buttressing the fact that firms do not really hold cash or cash equivalent in large quantity. Consequently, board skill (BSKILL), female leadership $(F L)$, foreign directors $(F D)$, director ownership $(D O W N)$, director compensation $(D C O M)$, board size (BSIZE), leverage (LEV) and profitability (PROF) show a mean of $0.47,0.24$, $0.35,0.14,7.9,9.8,0.55$ and 0.07 , which show that the sampled firm has a board size of a minimum of nine directors on the board with female occupying $25 \%$ and foreign directors at $35 \%$ and a well competent director with board skill of $47 \%$ on average. Furthermore, directors' holdings of this sampled firm consist of $15 \%$ with compensa-

\begin{tabular}{|c|c|c|c|c|c|c|c|c|c|}
\hline Variable & CASH & BSKILL & $F L$ & $F D$ & DOWN & DCOM & BSIZE & LEV & PROF \\
\hline Mean & 0.0994 & 0.4762 & 0.24751 & 0.35320 & 0.14519 & 7.91018 & 9.80952 & 0.55344 & 0.07106 \\
\hline Median & 0.0674 & 0 & 0.25 & 0.3529 & 0.0089 & 8.0554 & 9 & 0.53999 & 0.07162 \\
\hline Maximum & 0.6632 & 1 & 0.75 & 0.7778 & 0.9113 & 9.8887 & 18 & 1.61924 & 0.53305 \\
\hline Minimum & 0.0001 & 0 & 0 & 0 & 0 & 6.0631 & 4 & 0.17001 & -0.6615 \\
\hline Std. dev. & 0.10483 & 0.50114 & 0.14339 & 0.16861 & 0.23371 & 0.88392 & 2.85094 & 0.18998 & 0.10521 \\
\hline Skewness & 2.15871 & 0.09534 & 0.37903 & 0.17220 & 1.62604 & -0.17185 & 0.83021 & 1.32277 & -1.7717 \\
\hline Kurtosis & 9.22203 & 1.00909 & 3.34169 & 2.67705 & 4.6217 & 2.35512 & 3.54448 & 8.22803 & 21.2364 \\
\hline Jarque-Bera & 351.292 & 24.5005 & 4.23491 & 1.36531 & 80.8859 & 3.27073 & 18.7022 & 210.278 & 2113.87 \\
\hline Probability & 0 & 0.00005 & 0.12034 & 0.50527 & 0 & 0.19488 & 0.00008 & 0 & 0 \\
\hline Sum & 14.6138 & 70 & 36.3836 & 51.9201 & 21.3433 & 1162.79 & 1442 & 81.3551 & 10.4450 \\
\hline Sum sq. dev. & 1.60436 & 36.6666 & 3.00175 & 4.15050 & 7.97438 & 114.071 & 1186.66 & 5.26937 & 1.61599 \\
\hline Observations & 147 & 147 & 147 & 147 & 147 & 147 & 147 & 147 & 147 \\
\hline
\end{tabular}
tion of 8 million naira on average with the firm's profitability at $7 \%$ and a debt ratio at $55 \%$.

Table 2. Descriptive statistics

Source: Researcher's computation (2018). 
Table 3. Correlation analysis

\begin{tabular}{|c|c|c|c|c|c|c|c|c|c|}
\hline \multirow{2}{*}{ Variable } & \multirow{2}{*}{ CASH } & \multirow{2}{*}{ BSKILL } & \multicolumn{7}{|c|}{ Source: Researcher's computation (2018) } \\
\hline & & & $F L$ & $F D$ & DOWN & DCOM & BSIZE & LEV & PROF \\
\hline \multirow{3}{*}{ CASH } & 1.000000 & - & - & - & - & - & - & - & - \\
\hline & - & - & - & - & - & - & - & - & - \\
\hline & - & - & - & - & - & - & - & - & - \\
\hline \multirow{3}{*}{ BSKILL } & 0.058951 & 1.000000 & - & - & - & - & - & - & - \\
\hline & 0.711103 & - & - & - & - & - & - & - & - \\
\hline & 0.4782 & - & - & - & - & - & - & - & - \\
\hline \multirow{3}{*}{$G D$} & -0.15738 & -0.28412 & 1.000000 & - & - & - & - & - & - \\
\hline & -1.91901 & -3.56828 & - & - & - & - & - & - & - \\
\hline & 0.0569 & 0.0005 & - & - & - & - & - & - & - \\
\hline \multirow{3}{*}{$F D$} & -0.15315 & -0.22724 & 0.126919 & 1.000000 & - & - & - & - & - \\
\hline & -1.86620 & -2.80979 & 1.540768 & - & - & - & - & - & - \\
\hline & 0.0640 & 0.0056 & 0.1256 & - & - & - & - & - & - \\
\hline \multirow{3}{*}{ DOWN } & -0.00580 & 0.258453 & -0.02249 & -0.08312 & 1.000000 & - & - & - & - \\
\hline & -0.06985 & 3.221645 & -0.27090 & -1.00442 & - & - & - & - & - \\
\hline & 0.5444 & 0.0016 & 0.5869 & 0.3169 & - & - & - & - & - \\
\hline \multirow{3}{*}{ DCOM } & 0.052346 & -0.27738 & 0.070243 & -0.04068 & -0.14145 & 1.000000 & - & - & - \\
\hline & 0.631197 & -3.47657 & 0.847929 & -0.49028 & -1.72066 & - & - & - & - \\
\hline & 0.5289 & 0.0007 & 0.3979 & 0.6247 & 0.0874 & - & -- & & - \\
\hline \multirow{3}{*}{ BSIZE } & -0.10056 & 0.150213 & -0.31607 & -0.08223 & -0.03039 & 0.456981 & 1.000000 & - & - \\
\hline & -1.21712 & 1.829559 & -4.01129 & -0.99348 & -0.36614 & 6.186530 & - & - & - \\
\hline & 0.2255 & 0.0694 & 0.0001 & 0.3221 & 0.7148 & 0.0000 & - & - & - \\
\hline \multirow{3}{*}{ LEV } & -0.00595 & -0.08629 & 0.141712 & 0.087762 & 0.094639 & 0.265228 & 0.007910 & 1.000000 & - \\
\hline & -0.07165 & -1.04296 & 1.723832 & 1.060885 & 1.144747 & 3.312404 & 0.095251 & - & - \\
\hline & 0.5430 & 0.2987 & 0.0869 & 0.2905 & 0.2542 & 0.0012 & 0.5242 & - & - \\
\hline \multirow{3}{*}{ PROF } & 0.048511 & -0.03851 & 0.007402 & 0.134490 & -0.08160 & 0.014605 & -0.01357 & -0.039038 & 1.000000 \\
\hline & 0.584838 & -0.46409 & 0.089133 & 1.634319 & -0.98592 & 0.175892 & -0.16339 & -0.47044 & - \\
\hline & 0.5596 & 0.6433 & 0.5291 & 0.1044 & 0.3258 & 0.6606 & 0.5704 & 0.6387 & - \\
\hline
\end{tabular}

Table 3 depicts the correlation statistics on both constructs concurrently. It is a yardstick to attain if the data suffer any form of multicollinearity and to explore any possible association amid variables. However, the summary of this table proves that the correlation between construct does not exceed the $80 \%$ threshold as inferred in Ozordi et al. (2018). Hence, it proves the absence of multicollinearity.

Table 4. Random effects - Hausman test

Source: Researcher's computation (2018).

Correlated random effects - Hausman test

Equation: untitled

Test cross-section random effects

\begin{tabular}{l|c|c:c}
\hline \multicolumn{1}{|c|}{ Test summary } & $\begin{array}{c}\text { Chi-sq. } \\
\text { statistic }\end{array}$ & $\begin{array}{c}\text { Chi-sq. } \\
\text { d.f. }\end{array}$ & Prob. \\
\hline $\begin{array}{l}\text { Cross-section } \\
\text { random }\end{array}$ & 6.680598 & 8 & 0.0415 \\
\hline
\end{tabular}

Table 4 represents the predictability test on the appropriateness of what panel regression model to be employed under these specific rules: accept the alternate hypothesis (fixed effects model), if the $p$-value is statistically significant and accept the null hypothesis (random effects model) if the $p$-value isn't statistically significant. However, it is evident in Table 4 above that the $p$-value (0.0415) $<5 \%$, which implies the fixed effect model as the ideal yardstick for making the statistical decision.

Table 5 depicts the holistic summary of the fixed effect model already attested as the appropriate model required to explore the interconnectivity amid variables. However, the $R$-squared stands as at $48 \%$, implying the degree of functionality amidst the explanatory construct on the explained construct. Furthermore, a holistic fitness amidst variables interaction is evident by the Fisher ratio $p$-value of 0.00002 .

However, the first hypothesis states that there is no significant relationship between board skill and cash holding decisions in listed manufacturing firms in Nigeria. This proposition aligns with the claim, but statistically insignificant as evident 
Table 5. Panel regression analysis

Source: Researcher's computation (2018).

\begin{tabular}{|c|c|c|c|c|}
\hline Variable & Coefficient & Std. error & $t$-statistic & Prob. \\
\hline BSKILL & -0.009017 & 0.029634 & -0.304278 & 0.7615 \\
\hline$F L$ & -0.209297 & 0.084788 & -2.468483 & 0.0151 \\
\hline FOREPT & 0.069554 & 0.103751 & 0.670391 & 0.0240 \\
\hline DOWN & 0.034013 & 0.054778 & 0.620929 & 0.5359 \\
\hline DCOM & -0.014201 & 0.021679 & -0.655036 & 0.5138 \\
\hline$B S I Z E$ & -0.007196 & 0.006539 & -1.100483 & 0.2734 \\
\hline LEV & -0.002448 & 0.068284 & -0.035843 & 0.9715 \\
\hline PROF & -0.022303 & 0.091911 & -0.242654 & 0.8087 \\
\hline$C$ & 0.311865 & 0.194196 & 1.605926 & 0.1111 \\
\hline
\end{tabular}

Effects specification

\begin{tabular}{l|c|c|c}
\hline & Cross-section fixed (dummy variables) \\
\hline$R$-squared & 0.481067 & Mean dependent var & 0.099414 \\
Adjusted $R$-squared & 0.335401 & S.D. dependent var & 0.104828 \\
\hline S.E. of regression & 0.085459 & Akaike info criterion & -1.886825 \\
Sum squared resid & 0.832560 & Schwarz criterion & -1.215504 \\
F-statistic & 3.302542 & Durbin-Watson stat & 2.226693 \\
\hline Prob (F-statistic) & 0.000002 & & \\
\hline
\end{tabular}

by the $t$-statistics and $p$-values of -0.30 and 0.76 , respectively. This implies that the top level management skill level of qualification is not a major fulcrum for making cash holding decisions within an organization. Thus, the finding is akin to the work of Jamil, Anwar, Afzaal, Tariq, and Asif (2016) who averred that well-structured cash system is not mainly influenced by board skill.

Furthermore, the second assumption states that there is no significant association between female leadership and cash holding decisions in listed manufacturing firms in Nigeria. This does not align with the findings as shown in Table 5 with a $t$-statistics and $p$-values of -2.46 and 0.01 clearly depicting an adverse and significant association exist amid female leadership and cash holding decision. This outcome resonates with the work of averse (Ahsan \& Ullah, 2013) who averred that men are more confident in decision making than women and board lead by female directors do not make risky investment because of her risk appetite, there is no need for cash holding and that a negative relationship exists between female leadership and cash holding decision (Alam, 2010; Sabbadini \& Lim, 2011).

Consequently, the third hypothesis stands as follows: there is no significant relationship between foreign directors and cash holding decisions in listed manufacturing firms in Nigeria. The result as contained in (Table 5) reveals otherwise by the $t$-statistics and $p$-values of 0.67 and 0.02 , respectively. The outcome suggests an optimistic and significant association existing amid foreign directors and cash reserves. Implying an adequate proportion of foreign directors on top hierarchic in making decisions would transcend to a successful harnessing of ideas required to ascertain ensure the optimal cash reserves.

The fourth assumption stands as follows: there is no significant association between board ownership and cash holding decisions in listed manufacturing firms in Nigeria. The result as contained in Table 5 reveals the $t$-statistics and $p$-values of 0.62 and 0.54 does consonance with the null hypothesis. It clearly suggests that directors holding moves in the same direction with cash reserves, but such association is insignificant. This outcome is akin to the work of Kuan et al. (2011), Jamil, Anwar, Afzaal, Tariq, and Asif (2016) who averred that directors stakes in a firm would guide their instincts to pursue activities that would maximize the overall objective of the firm (Al-Najjar \& Clark, 2017; Amess et al., 2015).

Finally, the last hypothesis holds that there is no significant association between director compensation and cash holding decisions in listed manufacturing firms in Nigeria. This statement conforms with the outcome as displayed in Table 
5 showing the $t$-statistics and $p$-values of -0.65 and 0.51 , however, these findings are insignificant, implying that an adverse association exist amidst the director compensation and cash reserves. This outcome corroborates the work of Kuan et al. (2011) who averred that excess director compensation can result in underperformance of firms.

\section{CONCLUSION}

Cash holding decision is a very sensitive decision-making process of a firm, such decision helps in ascertaining the level of cash adequacy, check firms overtrading and stock of idle cash within its operations. The peculiar nature of this case necessitated an investigation on the implication of corporate dynamism on cash holding decision in thirty listed manufacturing firms in Nigeria spanning six years from 2012 to 2017. Findings from this study stand that foreign directors, director compensation and directors holding all have a positive association with cash holding decision. However, the director compensation is insignificant. On the other hand, board skill and gender diversity both have an adverse effect on the cash holding decision. The study, therefore, concludes that the decision to hold cash could be triggered by directors' holdings and foreign directors, because when they have stakes in any establishment, it triggers their aggressiveness toward engaging in an optimal and profitable operation that would boost their stakes (wealth). Also, foreign directors tend to exert some sort of expertise, which in turn rubs off on cash holding decisions, which can be justified due to the wider exposure they have as regards experience gathered from different parts of the world. The paper recommends that an appropriate policy on board mix inspired by core competence and parties having stakes in the company would help provide constructive ideas on the effective and efficient fund management within the manufacturing industries in Nigeria.

This study is limited by the fact that the data used for this work were generated from listed non-financial (industrial and consumable goods) sectors in Nigerian Stock Exchange. This will, in essence, limit the generalization of our findings over other sectors. However, the finding from this study remains valid. Future researchers can explore the financial sector, explore the comparative analysis amidst sectors on the subject matter.

\section{REFERENCES}

1. Adams, R. B., \& Ferreira, D. (2009). Women in the boardroom and their impact on governance and performance. Journal of Financial Economics, 94(2), 291309. https://doi.org/10.1016/j. jfineco.2008.10.007

2. Agnew, J., Pierluigi, B., \& Sunden, A. (2003). Portfolio Choice and Trading in a Large 401(k) Plan. American Economic Review, 93(1), 193-215. https://doi. org/10.1257/000282803321455223

3. Ahsan, S., \& Ullah, N. (2013). Impact of Cashflow Volatility on Cash-Cash Flow Sensitivity of Pakistani Firms. Journal of Business and Management, 8(1), 85-97. http://dx.doi. org/10.9790/487X-0818597
4. Alam, Z. (2010). An Empirical Analysis of the Determinants of Project Finance: Cash Flow Volatility and Correlation. Retrieved from https://papers.ssrn. com/sol3/papers.cfm?abstract_ id $=1571656$

5. Al-Najjar, B., \& Clark, E. (2017). Corporate governance and cash holdings in MENA: Evidence from internal and external governance practices. Research in International Business and Finance, 39, 1-12. https://doi.org/10.1016/j. ribaf.2016.07.030

6. Al Zararee, A. N., \& Al-Azzawi, A. (2014). The Impact of Free Cash Flow on Market Value of Firm. Global Review of Accounting and Finance, 5(2), 56-63. Retrieved from https://www.zuj.edu.jo/wpcontent/staff-research/economic/ dr.abdulrahman-al-azzawi/1.pdf

7. Amess, K., Banerji, S., \& Lampousis, A. (2015). Corporate cash holdings : Causes and consequences. International Review of Financial Analysis, 42, 421-433. https://doi.org/10.1016/j. irfa.2015.09.007

8. Asaleye, A. J., Adama, J. I., \& Ogunjobi, J. O. (2018). Financial sector and manufacturing sector performance: evidence from Nigeria. Investment Management and Financial Innovations, 15(3), 35-48. http://dx.doi.org/10.21511/ imfi.15(3).2018.03

9. Asaleye, A. J., Popoola, O., Lawal, A. I., Ogundipe, A., \& Ezenwoke, 
O. (2018). The credit channels of monetary policy transmission: implications on output and employment in Nigeria. Banks and Bank Systems, 13(4), 103118. http://dx.doi.org/10.21511/ bbs.13(4).2018.10

10. Barber, B. M., \& Odean, T. (2001). Boys will be boys: Gender, overconfidence, and common stock investment. Quarterly Journal of Economics, 261-292. Retrieved from https://papers.ssrn. $\mathrm{com} / \mathrm{sol} 3 /$ papers.cfm?abstract_ $\mathrm{id}=139415$

11. Barsky, R. B., Juster, F. T., Kimball, M. S., \& Shapiro, M. D. (1997). Preference parameters and behavioral heterogeneity: An experimental approach in the health and retirement study. The Quarterly Journal of Economics, 112(2), 537-579. https://doi. org/10.1162/003355397555280

12. Benavides, J., Berggrun, L., \& Perafan, H. (2016). Dividend payout policies: Evidence from Latin America. Finance Research Letters, 17, 197-210. https://doi. org/10.1016/j.frl.2016.03.012

13. Bhagat, S., \& Obreja, I. (2012). Employment, Corporate Investment and Cash Flow Uncertainty. Retrieved from https://papers.ssrn. com/sol3/papers.cfm?abstract_ $\mathrm{id}=1923829$

14. Connor, M. O., \& Yaghoubi, M. (2016). The influence of cash flow volatility on capital structure and the use of debt of different maturities. Journal of Corporate Finance, 38, 18-36. https://doi. org/10.1016/j.jcorpfin.2016.03.001

15. Eluyela, D. F., Akintimehin, O. O., Okere, W., Ozordi, E., Osuma, G. O., Ilogho, S. O., \& Oladipo, O. A. (2018a). Datasets for board meeting frequency and financial performance of Nigerian deposit money banks. Data in Brief, 19, 1852-1855. https://doi. org/10.1016/j.dib.2018.06.044

16. Eluyela, D. F., Akintimehin, O. O., Okere, W., Ozordi, E., Osuma, G. O., Ilogho, S. O., \& Oladipo, O. A. (2018b). Board meeting frequency and firm performance: examining the nexus in Nigerian deposit money banks. Heliyon, 4(10),
850. https://doi.org/10.1016/j. heliyon.2018.e00850

17. Faccio, M., Marchica, M., \& Mura, R. (2012). CEO gender, corporate risk-taking, and the efficiency of capital allocation. Journal of Corporate Finance, 39, 193-209. https://doi.org/10.1016/j.jcorpfin.2016.02.008

18. Fryman, C., \& Saks, R. E. (2010). Executive compensation: A new view from a long-term perspective. The Review of Financial Studies, 23(5), 20992138. https://doi.org/10.1093/rfs/ hhp120

19. Han, S., \& Box, P. O. (2017). Oil Price Volatility, an Economic Determinant of Earnings Volatility Empirical Analysis on Earnings Volatility of U. S. Oil and Gas companies between 1986-2016 (Master's Thesis). Aalto University School of Business Accounting. Retrieved from https://aaltodoc. aalto.fi/handle/123456789/27795

20. Hilgen, M. (2015, September). The determinants of cash holdings: Evidence from German listed firms (Master Thesis). Retrieved from https://essay.utwente.nl/68088/1/ Hilgen_MA_MB.pdf

21. Huang, J., \& Kisgen, D. (2013). Gender and Corporate Finance: Are Male Executives Overconfident Relative to Female Executives? Journal of Financial Economics, 108(3), 822-839. https://doi.org/10.1016/j. jfineco.2012.12.005

22. Jamil, S., Anwar, A., Afzaal, N., Tariq, A., \& Asif, M. (2016). Determinants of Corporate Cash Holdings: Empirical Analysis of Pakistani Firms. Journal of Economics and Finance, 7(3), 29-35. Retrieved from http:// www.iosrjournals.org/iosr-jef/ papers/Vol7-Issue3/Version-3/ D0703032935.pdf

23. Jeon, J. Q., \& Ryoo, J. (2013). How do foreign investors affect corporate policy? Evidence from Korea. International Review of Economics and Finance, 25, 52-65. https://doi.org/10.1016/j. iref.2012.05.001
24. Krejcie, R. V., \& Morgan, D. W. (1970). Determining Sample Size for Research Activities. Educational and Psychological Measurement, 30, 607-610. Retrieved from http://www.sciepub.com/reference/145556

25. Kuan, T., Li, C., \& Chu, S. (2011). Cash holdings and corporate governance in family-controlled firms. Journal of Business Research, 64(7), 757-764. https://doi. org/10.1016/j.jbusres.2010.07.004

26. Lambert, R., Leuz, C., \& Verrecchia, R. E. (2007). Accounting Information, Disclosure, and the Cost of Capital. Journal of Accounting Research, 45(2), 385-420. https://doi.org/10.1111/j.1475679X.2007.00238.x

27. Liu, Y., \& Mauer, D. (2011). Corporate cash holdings and CEO compensation incentives. Journal of Financial Economics, 102(1), 183-198. Retrieved from https:// econpapers.repec.org/RePEc:eee:jf inec:v:102:y:2011:i:1:p:183-198

28. Lückerath-Rovers, M. (2010). Women on Board and Firm Performance. Journal of Management \& Governance, 17(2), 491-509. Retrieved from https:// link.springer.com/article/10.1007/ s10997-011-9186-1

29. Mosavi, S. A., Karimipoua, M., Zarei, M., \& Heidari, M. (2015). The Relationship between cash Flow Volatility and Capital Structure in Tehran Stock Exchange. International Research Journal of Applied and Basic Sciences, 9(11), 20342040. Retrieved from http:// www.irjabs.com/files_site/ paperlist/r_2796_151211183937. pdf

30. Nadeem, M., Zaman, R., \& Saleem, I. (2017). Boardroom gender diversity and corporate sustainability practices: Evidence from Australian Securities Exchange-listed firms. Journal of Cleaner Production, 149, 874885. https://doi.org/10.1016/j. jclepro.2017.02.141

31. Oladipo, O. A., Iyoha, O. F., Fakile, A. S., Asaleye, A. J., \& Eluyela, D. F. (2019). Do government 
taxes have implications on manufacturing sector output ? evidence from Nigeria. Journal of Management Information and Decision Sciences, 22(3), 181-190. Retrieved from https:// www.abacademies.org/articles/ Do-government-taxes-haveimplications-on-manufacturingsector-output-Evidence-fromnigeria-1532-5806-22-3-141.pdf

32. Orens, R., \& Reheul, A. (2013). Do CEO demographics explain cash holdings in SMEs? European Management Journal, 31(6), 549563. https://doi.org/10.1016/j. emj.2013.01.003

33. Ozordi, E., Uwuigbe, U., Teddy, O., Tolulope, I., \& Eyitomi, G. A (2018). Corporate diversity and corporate social environmental disclosure of listed manufacturing companies in Nigeria. Problems and Perspectives in Management, 16(3), 229-244. https://doi. org/10.21511/ppm.16(3).2018.19

34. Peck-Ling, T., Nai-Chiek, A., \& Chee-Seong, L. (2016). Foreign Ownership, Foreign Directors and the Profitability of Malaysian Listed Companies. Procedia Social and Behavioral Sciences, 219, 580-588. https://doi. org/10.1016/j.sbspro.2016.05.037

35. Reyna, J. M. (2017). Estructura de propiedad y su efecto en la política de dividendos en el contexto mexicano. Contaduria y Administracion, 62(4), 1183-

1198. https://doi.org/10.1016/j. cya.2015.12.005

36. Sabbadini, A., \& Lim, M. (2011). Cash Flow Risk Management - in good times and bad. Paper presented at ERM Symposium 2011, Chicago, IL

37. Santosuosso, P. (2015). How Cash Flow Volatility Affects Debt Financing and Accounts Payable. International Journal of Economics and Finance, 7(8), 138145. https://doi.org/10.5539/ijef. v7n8p138

38. Schoubben, F., \& Uytbergen, S. (2014). The effect of gender diversity on corporate cash policy (36 p.). Retrieved from https:// limo.libis.be/primo-explore/fu lldisplay?docid=LIRIAS166553 2\&context=L\&vid=Lirias\&sear ch_scope $=$ Lirias $\&$ tab $=$ default tab\&lang=en_US\&fromSitemap $=1$

39. Scordis, N. A., Barrese, J., \& Wang, P. (2017). The Impact of Cash Flow Volatility on Systematic Risk. Western Risk and Insurance Association, 31(1), 43-71.

Retrieved from https://www.jstor. org/stable/41946281?seq=1\#page_ scan_tab_contents

40. Sunden, A., \& Surette, B. J. (1998). Gender differences in the Allocation of Assets in Retirement Savings Plans. American Economic Review, 88(2), 207-211. Retrieved from https://www.jstor.org/ stable/116920?seq=1\#page_scan_ tab_contents

41. Thi, D., \& Nhan, T. (2016). A Review of Cash Holding and Corporate Governance Mechanisms in Transition Economies. International Review of Management and Marketing, 6, 354-358. Retrieved from https:// www.econjournals.com/index. $\mathrm{php} / \mathrm{irmm} /$ article/view/5691

42. Thi, D., \& Nhan, T. (2018). Cash holding, Corporate governance mechanisms and Firm value in transition economies: $A$ study of listed corporations in Vietnam. Retrieved from http:// digilib.k.utb.cz/bitstream/ handle/10563/42639/do_2018_ dp.pdf? sequence $=1$ \&isAllowed $=y$

43. Uwalomwa, U., Olamide, O., \& Francis, I. (2015). The Effects of Corporate Governance Mechanisms on Firms Dividend Payout Policy in Nigeria. https://doi. org/10.5171/2015.313679

44. Vo, D., \& Phan, T. (2013). Corporate Governance and Firm Performance: Empirical Evidence from Vietnam. Journal of Economic Development, 21(8), 62-78. Retrieved from https://www.researchgate.net/ publication/301224738_Corporate_Governance_and_Firm's Performance_Empirical_Evidence_from_Vietnam 


\section{APPENDIX A}

Table A1. Random effect regression analysis

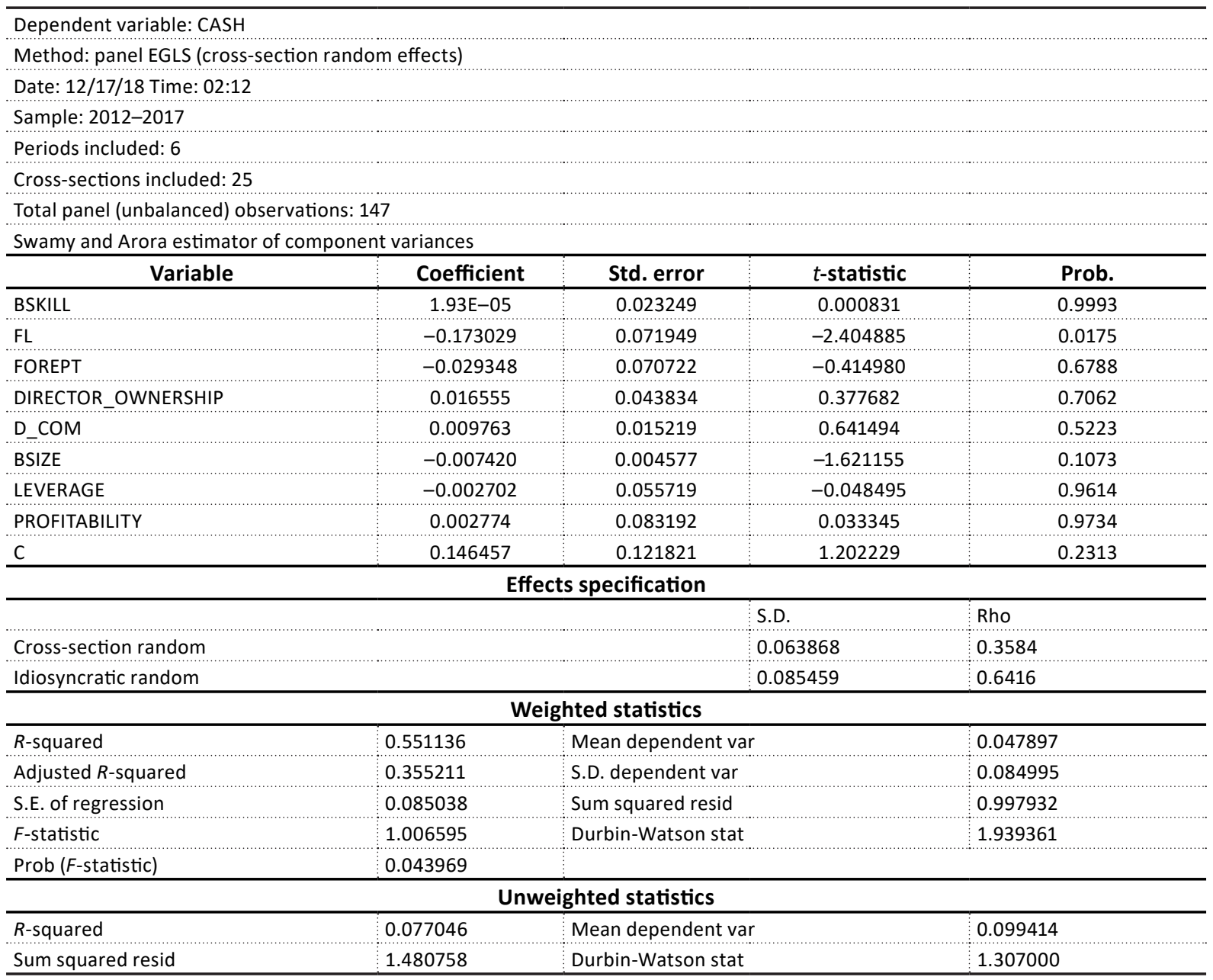

